\title{
ANALISIS PERLAKUAN AKUNTANSI ASET BIOLOGIS TINJAUAN TEORITIS ADOPSI IAS 41
}

\author{
NUR AFNI YUNITA DAN NUR RAMADANI
}

Fakultas Ekonomi dan Bisnis, Universitas Malikussaleh, Lhokseumawe

This study animed to determine how the treatment of biological assets in PTPN IV and the comparison of the tretment of biological assets based on the standars applied by PTPN IV with IAS 41. The objects in this study were the treatment of biological assets in PTPN IV. The research method used was descriptive qualitative research. The reseults of this study indicated that the recongnition, presentation, and disclosure for biological assets at PTPN IV was in accordance with IAS 41, but for measuring biological assets using the acquisition price while IAS 41 measures biological assets using fair value.

Keywords: Biological Assets, IAS 41, Fair Value, Accounting Treatment 


\section{PENDAHULUAN}

Laporan Keuangan merupakan hasil kinerja suatu perusahaan selama satu periode. Dalam Laporan Keuangan terdapat laporan posisi keuangan yang menyediakan informasi mengenai posisi keuangan suatu perusahaan. Laporan posisi keuangan harus menyajikan secara terpisah kategori dan klasifikasi utama aset dan liabilitas. Pada industri agrikultur aset menjadi bagian yang cukup menarik perhatian, karena pada perusahaan agrikultur berbeda dengan perusahaan manufaktur pada umunya, perusahaan yang bergerak dibidang agrikultur memiliki aset yang berbentuk makhluk hidup yang disebut dengan aset biologis. IAS 41 mendefinisikan aset biologis sebagai "Biological asset is a living animal or plant" yaitu, aset biologis sebagai tumbuh - tumbuhan dan hewan - hewan yang hidup yang dikendalikan atau dikuasai oleh perusahaan sebagai akibat dari kejadian masa lampau.

Bagi perusahaan agrikultur aset biologis merupakan kepentingan utama karena entitas ini memperoleh pendapatan dari aset biologisnya sendiri. Oleh karena itu, aset biologis harus dikelola dengan baik agar perusahaan bisa mendapatkan keuntungan dan manfaat serta tercapainya tujuan perusahaan.

Perkembangan yang terjadi pada industri agrikultur memiliki banyak kemajuan karena hasil produksi dari aktivitas agrikultur mengalami peningkatan sehingga perusahaan agrikultur mampu menembus pasar ekspor, oleh karena itu hal ini merupakan peluang yang baik bagi perusahaan agrikultur. Banyaknya perusahaan yang bergerak dalam industri agrikultur, membuat para pengusaha tentunya pasti akan membutuhkan penilaian terhadap aset biologis mereka. Aset biologis perlu diakui di dalam laporan posisi keuangan dan mengakui pendapatannya di dalam Laporan Laba Rugi Komprehensif.

Pengusaha agrikultur dituntut untuk memiliki sistem perhitungan dan penilaian tersendiri, agar data-data yang berupa aset tersebut dapat dinilai dengan andal serta berguna apabila suatu saat nanti peruahaan tersebut memerlukan adanya investasi untuk dorongan daya produksi perusahaan. Oleh karena itu, maka perusahaan harus melaporkan kinerjanya dalam laporan keuangan yang comparable dengan perusahaan lain. Laporan keuangan harus dibuat sesuai dengan standar akuntansi yang berlaku secara global untuk memudahkan para pengusaha perkebunan yang memiliki hubungan kerjasama dengan investror asing maupun digunakan saat diperbandingkan dengan laporan keuangan perusahaan multinasional yang sejenis (Rafika, 2013).

Salah satu standar akuntansi yang berstandar global adalah International Accounting Reporting Standar (IFRS) adalah standar, interpretasi, dan kerangka yang diadopsi oleh badan penyusun standar akuntansi internasional yang dikenal dengan International Accounting Standards Board (IASB). Beberapa standar yang membentuk IFRS dulunya dikenal dengan nama International Accounting Standars (IAS). IAS diterbitkan oleh suatu badan yang dikenal dengan Internatonal Accounting Standars Committee (IASC) pada kurun waktu antara tahun 1973-2001. Hingga maret 2002, IAS telah menerbitkan 41 IAS dan 34 SIC (Standing Interpretations Committee) Interpretations. Beberapa di antaranya telah diubah atau diganti oleh IASB. Standar yang masih tersisa dipandang sebagai payung bagi IFRS. Salah satunya adalah standar mengenai akuntansi untuk industri perkebunan, peraturan ini ada pada IAS 41 tentang Accounting for Agriculture Assets. Peraturan dalam IAS 41 melingkupi standar akuntansi yang bisa diterapkan pada sektor industri agrikultur.

Ikatan Akuntan Indonesia (IAI) sebagai organisasi yang berwenang dalam membuat standar akuntansi di Indonesia telah melakukan langkah - langkah peyeragaman standar akuntansi keuangan. Sejak tahun 1994, IAI telah melaksanakan program harmonisasi dan adaptasi standar akuntansi internasional dalam rangka pengembangan standar akuntansinya (SAK 2009). Pada Desember 2009 IAI telah mengumumkan rencana kovergensi standar akuntansi lokalnya yaitu Pernyataan Standar Akuntansi Keuangan (PSAK) dengan International Accounting Standards (IFRS). Beberapa standar akuntansi keuangan berbasis IFRS telah mengalami perubahan yang signifikan dan berpotensi menciptakan goncangan besar dari dunia bisnis, seperti pada saat pengkonversian pertaman pada tahun 2012 lalu. Oleh karena itu, 
perusahaan agrikultur akan sangat mengalami perubahan yang sangat signifikan apabila perusahaan menggunakan standar yang berlaku global seperti IAS 41 sebagai dasar untuk penilaian aset biologisnya.

Namun, dalam penerapannya IFRS dihadapkan pada beberapa permasalahan, khususnya pada pengaplikasian IAS 41 mengenai adanya perubahan pengukuran serta pelaporan keuangan akuntansi yang pada awalnya berdasarkan pada biaya historis (historical cost) menuju pengukuran dan pelaporan berdasarkan nilai wajar (fair value). Perubahan penilaian yang mendasar ini, membuat beberapa perusahaan memiliki keandalan saat menerapkannya. Terlebih karena berkaitan dengan pengukurannya yang tentunya akan berpengaruh pada pelaporan aset biologis dalam laporan keuangan sebagai tujuan akhir dari perlakuan akuntansi itu sendiri.

Aset biologis diukur pada saat pengakuan awal dan diukur dengan nilai wajar yang diukur berdasarkan nilai aset biologis pada pasar aktif, namun jika tidak terdapat pasar aktif penilai aset biologis dapat diukur berdasarkan harga pasar terkini, harga pasar untuk aset biologis yang sejenis ataupun dengan harga pasar yang menjadi nilai patokan dari aset biologis dalam sektor agrikultur jika tidak dapat ditemukan harga pasar yang memastikan nilai aset dari aset biologis, maka nilai arus kas bersih yang diharapkan dari aset setelah didiskontokan dengan tarif pajak yang berlaku dan jika tidak terdapat nilai aset biologis setelah dikurangi dengan akumulasi penyusutan dan akumulasi kerugian lainnya.

Aset biologis sendiri hanya dapat diakui hanya jika perusahaan mengendalikan aset biologis tersebut sebagai hasil dari transaksi masa lalu yang memungkinkan untuk memperoleh hasilnya dimasa depan yang akan mengalir kedalam perusahaan dan mempunyai nilai wajar atau biaya aset dapat diukur secara andal. Dalam aktivitas agrikultur sendiri, pengendalian dapat dibuktikan dengan kepemilikannya terhadap aset biologis itu sendiri. Terdapat asumsi bahwa nilai wajar dari aset biologis dapat diukur secara andal, namun asumsi tersebut dapat dibantah hanya pada saat pengakuan awal aset biologis yang harga kuotasi pasarnya tidak tersedia dan yang alternatif pen- gukuran nilai wajarnya secara jelas tidak dapat diandalkan. Dalam laporan keuangan aset biologis dapat diakui sebagai aset lancar, apanila masa manfaat kurang dari satu tahun. Diakui sebagai aset tidak lancar, apabila masa manfaat lebih dari satu tahun (Sharlica Evelyn, 2017).

Pengukuran aset biologis dengan menggunakan konsep fair value menghabiskan biaya yang lebih tinggi dibandingkan dengan manfaat yang diperoleh sehingga tidak sebanding dengan benefit yang dicapai. Terkait dengan peningkatan earnings volatility karena penggunaan fair value, bahkan di prancis auditor memberikan label "health warning" pada aset biologis perusahaan agar pengguna menyadari bahwa adanya ketidakpastian dalam penilaian aset biologis (Eald dan Herbhon, 2011). Selain itu, terdapat beberapa pihak yang menentang akuntansi yang berdasarkan nilai pasar menggunakan argumentasi bahwa market value accounting kurang dapat dipercaya dan menjadi halangan utama dalam penerapannya. Mereka menganggap bahwa subjektivitas dari estimasi nilai wajar pada aset dan liabilitas tanpa pasar yang liquid membuat laporan keuangan menjadi kehilangan relevansinya. Meskipun banyak pihak yang menganggap bahwa subjektivitas selalu menjadi bagian dari akuntansi yakni dalam masalah penggabungan usaha, metode pembelian dan dalam pengukuran.

PT. Perkebunan Nusantara IV atau disingkat PTPN IV merupakan salah satu perusahaan agrikultur di Indonesia yang mengelola aset biologis sebagai komoditas utamanya. PTPN IV merupakan sebuah anak usaha perseroan BUMN yang berkantor pusat di Medan, Sumatra Utara. PTPN IV bergerak dibidang agrobisnis dan agroindustri antara lain pembudidayaan tanaman, pengolahan, dan penjualan produk kelapa sawit dan teh.

Aset biologis merupakan fenomena yang menarik untuk diteliti karena aset biologis merupakan aset yang unik, dimana aset ini mengalami transformasi pertumbuhan bahkan setelah aset biologis menghasilkan output. Perusahaan agrikultur di Indonesia seharusnya sudah mulai menerapkan IAS 41 untuk perlakuan akuntansi aset biologisnya agar perusahaan dapat menyajikan informasi yang relevan dan informatif serta seragam dengan perusahaan-perusahaan internasional. Pada PTPN 
IV tahun 2015 perusahaan ini mencatat nilai aset biologis untuk tanaman menghasilkan sebesar RP. 4.008.183.860.713 dan pada tahun 2016 perusahaan ini mencatat nilai aset biologis lebih besar dibandingkan pada tahun sebelumnya yaitu sebesar Rp. 4.468.334.968.763 terdapat pebedaan nilai aset biologis sebasar 4,78 \% ditahun 2016 dengan selisih sebesar Rp. 460.151.108.050. Hal ini membuat peneliti tertarik untuk meneliti bagaimana perlakuan akuntasi aset biologis yang diterapkan oleh PTPN IV apakah peningkatan pencataatan aset biologis pada tahun 2016 ini dikarenakan pengukuran aset biologis berdasarkan nilai wajar

Walaupun aset biologis bukan hal yang baru lagi tetapi pada umumnya masih banyak mahasiswa yang belum mengenal aset biologis. Oleh karena itu peneliti ingin mengkaji lebih dalam megenai aset biologis. Berdasarkan latar belakang tersebut maka peneliti mengangkat permasalahan ini dengan judul: "Analisis Perlakuan Akuntansi Aset Biologis (Tinjauan Teoritis Adopsi IAS 41)".

\section{LANDASAN TEORI}

\section{Aset Biologis}

Aset biologis merupakan salah satu aset dari aktivitas agrikultur. Aset biologis didefinisikan sebagai tanaman hidup pertanian maupun perkebunan dan hewan ternak yang dimiliki dan diolah oleh prusahaan dengan tujuan agar perusahaan mendapatkan keuntungan, seperti yang didefinisikan dalam IAS 41: "Biological asset is a living animal or plant"

Apabila dikaitkan dengan karakteristik yang dimiliki oleh aset, maka aset biologis dapat dijabarkan sebagai tanaman pertanian atau hewan ternak yang dimiliki oleh perusahaan yang diperoleh dari kegiatan masa lalu (Ridwan 2011). Aset biologis terus mengalami perubahan. Mereka tumbuh, merosot dan menghasilkan. Akibatnya terjadi perubahan kuantitatif dan kualitatif pada sifat aset biologis. Perubahan tersebut dikenal sebagai transformasi biologis. Produk panen dari perubahan sifat aset biologis dikenal sebagai produk pertanian.

\section{Karakteristik Aset Biologis}

Karakteristik khusus yang membedakan aset biologis dengan aset lainnya yaitu bahwa aset biologis mengalami transformasi biologis. Tranformasi biologis merupakan proses pertumbuhan, degenerasi, produksi, dan prokreasi yang disebabkan perubahan kualitatif dan kuantitatif pada makhluk hidup dan menghasilkan aset baru dalam bentuk produk agrikultur atau aset biologis tambahan pada jenis yang sama.

\section{Jenis Aset Biologis}

Berdasarkan masa manfaat atau jangka waktu transformasi biologisnya, aset biologis dapat dikelompokkan menjadi 2 jenis, yaitu:

1. Aset Biologis Jangka Pendek (Short Term Biological Assets)

Aset biologis yang memiliki masa manfaat/ masa transformasi biologis kurang dari atau sampai 1 (satu) tahun.

2. Aset Biologis Jangka Panjang (Long Term Biological Assets)

Aset biologis yang memiliki masa manfaat/ masa tranformasi biologis lebih dari 1 (satu) tahun.

\section{Pengakuan Aset Biologis}

Aset biologis dalam laporan keuangan dapat diakui sebagai aset lancar maupun aset tidak lancar sesuai dengan jangka waktu transformasi biologis dari aset biologis yang bersangkutan. Aset biologis diakui ke dalam aset lancar ketika masa manfaat/masa transformasi biologisnya kurang dari atau sampai dengan 1 (satu) tahun dan diakui sebagai aset tidak lancar jika masa manfaat/masa transfomasi biologisnya lebih dari 1 (satu) tahun (Ridwan.A, 2011: 14).

\section{Pengukuran Aset Biologis}

Aset biologis diukur pada saat pengakuan awal dan pada akhir periode pelaporan berdasarkan nilai wajar dikurangi dengan estimasi biaya penjualan (point of sale), kecuali jika nilai wajar tidak dapat diukur secara andal (IAS 41:12).

Hasil panen agrikultur diukur pada nilai wajar dikurangi estimasi biaya penjualan pada titik panen, yang merupakan biaya pada saat penerapan IAS 2 Persediaan atau standar lain yang berlaku (IAS 41:13).

Pengukuran nilai wajar aset biologis atau 
produk agrikultur dapat didukung dengan mengelompokkan aset biologis atau produk agrikultur sesuai dengan atribut yang signifikan; sebagai contoh, berdasarkan usia atau kualitas. Entitas memilih atribut yang sesuai dengan atribut yang digunakan di pasar sebagai dasar penentuan harga (IAS 41:15).

\section{Penyajian dan Pengungkapan Aset Biologis}

Perusahaan harus menyajikan nilai tercatat aset biologis secara terpisah di laporan keuangan. Perusahaan harus mengungkapkan total/agregat keuntungan atau kerugian yang timbul selama periode berjalan atas pengakuan awal aset biologis dan produk hasil pertanian dan dari perubahan dalam nilai wajar dikurangi dengan estimasi biaya saat penjualan atas aset biologis tersebut. Perusahaan juga harus menyajikan deskripsi untuk setiap kelompok aset biologis.

\section{METODE PENELITIAN}

Penelitian ini merupakan penelitian deskriptif kualitatif yaitu peneliti menganalisis perlakuan akuntansi aset biologis pada PT. Perkebunan Nusantara IV selama satu tahun terakhir, kemudian membandingkannya dengan IAS 41 untuk melihat apakah PT. Perkebunan Nusantara IV telah menggunakan IAS 41 dalam perlakuan akuntansinya. Penelitian ini bersifat studi kasus dengan ruang lingkup penelitian pada PT. Perkebunan Nusantara IV yang berkantor pusat di Medan, Sumatra Utara.

\section{Lokasi Penelitian}

Lokasi penelitian dalam penulisan ini adalah perusahaan milik Negara yang bergerak di bidang agrikultur yaitu PT. Perkebunan Nusantara IV yang beralamat di Jl. Letjen Suprapto No. 2 Medan - 20151 dengan alamat E-Mail : ptpnusantara4 [at] ptpn4.co.id dan faxmile : +62-61-4573117.

\section{Jenis Data}

Jenis data yang digunakan dalam penulisan ini adalah sebagai berikut:

1. Data kualitatif, yaitu data dari perusahaan dalam bentuk informasi baik lisan maupun tulisan seperti sejarah berdirinya perusahaan, struktur organisasi perusahaan, serta data-data lain yang sifatnya kualitatif yang dibutuhkan dalam rangkan penulisan.

2. Data kuantitatif, yaitu data yang berupa angka-angka seperti besarnya nilai aset biologis yang diakui oleh perusahaan dalam laporan keuangan, serta data-data lain yang dibutuhkan dalam rangka penulisan.

\section{Sumber Data}

Adapun sumber data yang digunakan penulis, yaitu:

1. Data Primer, yaitu data yang diperoleh melalui pengamatan atau wawancara langsung dengan pihak perusahaan.

2. Data Sekunder, yaitu data data yang diperoleh melalui dokumen-dokumen atau arsip-arsip perusahaan yang berkaitan dengan penulisan berupa laporan keuangan serta catatan-catatan mengenai pengakuan dan pengukuran aset biologis.

\section{Teknik Pengumpulan Data}

Untuk mendapatkan data-data sehubungan dengan penelitian ini, maka penulis menggunakan metode sebagai berikut:

1. Penelitian kepustakaan (library research), yaitu memahami dengan baik teori yang menyangkut pokok permasalahan yang diteliti dengan cara mengkaji dan menelaah bukubuku serta artikel-artikel yang berhubungan dengan permasalahan penelitian.

2. Penelitian lapangan (field research), yaitu kegiatan pengumpulan data yang dilakukan dengan meninjau langsung pada objek dan sasaran yang diteliti pada PT. Perkebunan Nusantara IV Medan. Adapun penelitian lapangan meliputi:

a. Wawancara (interview), yaitu penulis mengadakan wawancara dengan pihak perusahaan yang diwakili oleh staf perusahaan yang berwenang guna memperoleh informasi yang dibutuhkan sehingga penulis mendapatkan gambaran mengenai proses pengakuan dan pengukuran aset biologis yang dilakukan oleh perusahaan.

b. Pengamatan (observasi), yaitu penulis mengadakan pengamatan langsung kepada 
objek dan sasaran yang akan diteliti, guna memperoleh data dan bahan informasi pada PT. Perkebunan Nusantara IV Medan.

\section{Metode Analisis}

Penelitian ini bersifat deskriptif kualitatif dengan tujuan untuk memberikan gambaran awal mengenai pengukuran, pengakuan, dan pengungkapan aset biologis berdasarkan standar yang berlaku di PT. Perkebunan Nusantara IV. Menurut Indriantoro dan Supomo (2009), penelitian deskriptif yang bersifat kualitatif adalah penelitian tentang status objek penelitian yang berhubungan dengan proses secara rinci dari keseluruhan personalia.

Penelitian deskriptif ini merupakan bentuk dari penelitian non-hipotesis yang tidak membutuhkan adanya perumusan hipotesis. Beberapa langkah yang dilakukan dalam analisis data adalah sebagai berikut:

1. Mengidentifikasi format pelaporan dan standar yang digunakan dalam kaitannya dengan pelaporan aset biologis;

2. Melakukan pengklasifikasian aset biologis yang dimiliki oleh PT. Perkebunan Nusantara IV

3. Menganalisis penerapan aktivitas agrikultur, khususnya tentang pengakuan pengukuran, dan pengungkapan aset biologis perusahaan;

4. Membandingkan penerapan aset biologis dan akun-akun yang berhubungan dengan aktivitas agrikultur berdasarkan standar yang telah diterapkan oleh perusahaan dengan penerapan berdasarkan IAS 41 Agrikultur;

\section{Analisis Data}

Metode pengumpulan data dalam penelitian ini juga menunjukkan metode analisis data dalam penelitian ini. Analisis data dilakukan dari awal hingga akhir penelitian. Pada penelitian ini analisis data adalah dengan cara:

1. Mencatat hasil pengumpulan data dari metode Content analysis yang digunakan dalam penelitian.

2. Melakukan perbandingan antara metode yang digunakan perusahaan saat ini dengan IAS 41.

3. Melakukan konfirmasi dengan informasi sebelumnya.
Jika semua telah dianalisis kemudian peneliti menarik kesimpulan dan data yang diteliti kemudian dibuat laporan apakah sudah sesuai atau belum agar dapat dipahami benar oleh peneliti. Interpretasi data dilakukan dengan penjelasan dan menulis laporan. Menurut Chariri (2006), analisis tidak bisa dipisahkan dari proses pengumpulan data dan dilakukan proses selanjutnya yaitu dianalisis agar hasilnya kredibel.

\section{PEMBAHASAN}

\section{Analisis Pengakuan Pengukuran Aset Biologis}

Dari hasil penelitian yang telah dilakukan di PT Perkebunan Nusantara IV dan berdasarkan rujukan dari IAS 41 untuk pengakuan aset biologis yang ada di PT Perkebunan Nusantara IV telah sesuai. Hal ini dikarenakan dalam IAS 41, entitas harus mengakui aset biologis atau pertanian berproduksi hanya ketika entitas mengendalikan aset biologis sebagaiakibat dari peristiwa masa lalu, terdapat kemungkinan bahwa manfaat ekonomi masa depam akan mengalir ke entitas dan nilai wajar atau biaya aset dapat diukur secara andal. Oleh karena itu IAS 41 menyarankan entitas mengakui aset biologis sebagai aset biologis belum dewasa dan aset biologis dewasa. Begitu juga dengan PT Perkebunan Nusantara IV, perusahaan ini mengakui aset tanaman hanya ketika perusahaan mengendalikan aset sebagai peristiwa masa lalu, dan terdapat kemungkinan manfaat ekonomis masa depan akan mengalir ke perusahaan dan biaya perolehan tanaman belum menghasilkan sebesar akumulasi biaya yang dikapitalisasi ke tanaman belum menghasilkan tersebut serta biaya perolehan tanaman menghasilkan sebesar nilai tercatat tanaman belum menghasilkan yang direklsifikasikan ketanaman menghasilkan. Oleh karena itu pada PT Perkebunan Nusantara IV pengakuan aset biologis dibedakan menjadi dua yaitu, Tanaman Belum Menghasilkan (TBM) dan Tanaman Menghasilkan (TM). Seandainya PTPN IV telah menerapkan standar ini maka perusahaan mengakui tanaman belum menghasilkan sebagai aset belum dewasa dan tanaman telah menghasilkan sebagai aset biologis dewasa. Untuk pengakuan aset biologisnya sesuai dengan IAS 41, perbedaannya hanya terletak pada istilah saja. 
Untuk pengukuran aset biologis pada PTPN IV ini tidak sesuai dengan IAS 41 hal ini disebabkan dalam IAS 41 aset biologis diukur pada saat pengakuan awal dan pada akhir periode pelaporan berdasarkan nilai wajar dikurangi dengan estimasi biaya penjualan (point of sale), kecuali jika nilai wajar tidak dapat diukur secara andal. Berbeda dengan pengukuran yang dilakukan oleh PTPN IV, dimana aset tanaman perkebunan diukur berdasarkan kelompoknya masing-masing. Untuk aset tanaman belum menghasilkan diukur berdasarkan harga perolehan dari tanaman belum menghasilkan yang terdiri dari biaya langsung seperti biaya-biaya pembibitan, persiapan lahan, penanaman, pemupukan dan pemeliharaan untuk tanaman. Selain itu, ada biaya tidak langsung seperti alokasi biaya umum dan administrasi. Jadi dapat disimpulkan bahwa harga perolehan dari tanaman belum menghasilkan diperoleh dari mengkapitalisasi biaya langsung dan biaya tidak langsung yang berhubungan dengan tanaman perkebunan yang ada di PTPN IV.

Pada tanaman menghasilkan dilakukan pengukuran berdasarkan nilai yang telah direklasifikasi dari tanaman belum menghasilkan. Untuk kapitalisasi biaya langsung dan biaya tidak langsung yang berhubungan dengan tanaman perkebunan tidak lagi dilakukan hal ini disebabkan karena biaya-biaya tersebut dianggap tidak dapat lagi memberikan kontribusi bagi perkembangan tanaman telah menghasilkan.karena tanaman telah menghasilkan sudah mampu memberikan kontribusi manfaat kepada perusahaan yang berupa hasil panen maka perlu dilakukan penyusutan untuk mengakui manfaat dari tanaman telah menghasilkan pada setiap periodenya. Penyusutan dihitung berdasarkan taksiran masa manfaat ekonomis tanaman. Dimana pada tanaman kelapa sawit memiliki masa manfaat 25 tahun dengan penyusutan sebesar $2 \%$ pertahun. Pada tanaman teh memiliki masa manfaat 50 tahun dengan penyusutan sebesar $4 \%$ pertahun.

Untuk hasil panen agrikultur IAS 41 mengukur dengan menggunakan nilai wajar dikurangi estimasi biaya penjuaan pada titik panen, yang merupakan biaya pada saat penerapan IAS 2 persediaan. Hal ini juga berbeda dengan PTPN IV dimana perusahaan ini mengukur hasil panen yang diakui sebagai persediaan mengunakan harga yang lebih rendah antara harga perolehan dan nialai realisasi bersih.

Harga perolehan dari hasil panen ini didapatkan dari mengkapitalisasi biaya-biaya yang dikeluarkan untuk memanen hasil panenan dari tanaman induk sampai dengan hasil panen tersebut siap untuk dijual. Sedangkan nilai realisasi bersih diperoleh dari estimasi harga jual dari hasil panenan setelah dikurangi dengan biaya penjualan seperti komisi penjualan. Selain hasil panenan berupa produk utama buah kelapa sawit dan daum teh pada PTPN IV, tanaman telah menghasilkan juga dapat menghasilkan produk sampingan berupa bibit tanaman yang dapat dijadikan persediaan dan ada juga bibit tanaman baru pada PTPN IV. Perbedaan ini terjadi karena penggunaan nilai wajar (fair value) dianggap kurang andal. Sehingga perusahaan mengukur nilai aset biologisnya dengan mengkapitalisasi biay-biaya yang telah dikeluarkan sebelumnya

\section{Analisis Penyajian dan Pengungkapan Aset Biologis}

Dari hasil penelitian yang telah dilakukan pada PT Perkebunan Nusantara IV dan rujukan IAS 41, penulis menemukan hasil bahwa penyajian untuk aset biologis pada PTPN IV telah sesuai dengan IAS 41. PTPN IV telah menyajikan aset biologis baik itu tanaman belum menghasilkan maupun tanaman telah menghasilkan pada aset tidak lancar didalam laporan posisi keuangan. Untuk hasil panenan setelah dipanen PTPN IV mengakuinya sebagai persediaan, didalam laporan posisi keuangan disajikan dalam kelompok aset lancar.

Untuk pengungkapan aset pada PTPN IV dengan IAS 41 juga telah sesuai, hal ini dikarenakan dalam IAS 41 mengharuskan perusahaan untuk mendeskripsikan setiap kelompok aset biologis yang dimiliki oleh perusahaan baik itu pengungkapan dalam bentuk narasi maupun deskripsi, metode penyusutan yang digunakan, masa manfaat atau tarif penyusutan yang digunakan oleh perusahaan. Untuk pengungkapan di PTPN IV, perusahaan ini telah mengungkapkan jenis - jenis aset tanaman yang dimiliki, metode penyusutan yang digunakan serta masa manfaat atau tarif penyusutan untuk aset tanaman tersebut. Selain itu perusa- 
haan juga mengungkapkan kebijakan - kebijakan perusahaan yang tercantum didalam catatan atas laporan keuangan

\section{KESIMPULAN}

Berdasarkan penelitian yang telah dilakukan pada PT Perkebunan Nusantara IV, maka diperoleh kesimpulan sebagai berukut:

1. Pengakuan aset biologis pada PTPN IV diakui kedalam dua kelompok yaitu Tanaman Belum Menghasilkan (TBM) dan Tanaman telah Menghasilkan (TM). Aset biologis pada PTPN IV diukur dengan menggunakan harga perolehan. Penyajian aset biologis belum dewasa dan aset biologis dewasa disajikan dalam laporan posisi keuangan pada kelompok aset tidak lancar. Untuk produk agrikultur pada saat panen diakui sebagai persediaan dan disajikan dalam kelompok aset lancar. PTPN IV mengungkapkan aset biologis yang dimilikinya, metode penyusutan yang digunakan, masa manfaat atau tarif penyusutan yang digunakan, akumulasi penyusutan, serta pengungkapan-pengungkapan lainnya yang berkaitan dengan aset biologis.

2. Pengakuan, penyajian dan pengungkapan aset biologis yang diterapkan oleh PTPN IV telah sesuai dengan IAS 41. Sedangkan pengukuran yang diterapkan oleh PTPN IV belum sesuai dengan IAS 41, karena PTPN IV mengukur aset biologisnya dengan menggunakan harga perolehan tidak seperti IAS 41 yang menggunakan nilai wajar dalam pengukurannya. Perbedaan ini dikarenakan perusahaan kesulitan dalam menentukan nilai wajar.

\section{SARAN}

Berdasarkan pembahasan dan hasil analisis serta beberapa kesimpulan pada penelitian ini, saran yang dapat diberikan melalui hasil penelitian ini, adalah:

1. Bagi Perusahaan kelemahan dari kesulitan untuk mengidentifikasi biaya - biaya yang terkait dengan aset biologis berupa tanaman perkebunan harus segera diatasi agar informasi yang diberikan lebih informatif dan tidak mengalami salah saji.

2. Bagi penelitian selanjutnya diharapkan dapat memberikan gambaran pengakuan, pengukuran, penyajian dan pengungkapan aset biologis berupa hewan ternak, tanaman semusim (Agrobotani), yaitu tanaman yang memiliki masa manfaat dibawah atau sampai dengan satu tahun agar dapat melengkapi kekurangan pada penelitian ini.

3. Bagi peneliti selanjutnya diharapkan dapat menambah periode tahun penelitian selama 2 atau 3 tahun untuk dapat melengkapi kekurangan pada penelitian ini yang hanya mampu menggunakan periode satu tahun.

4. Bagi peneliti selanjutnya agar dapat mengambil penelitian pada perusahaan perkebunan atau perternakan yang memang telah menerapkan IFRS agar dapat melengkapi kekurangan dalam penelitian ini. 


\section{REFERENSI}

Adita, Kiswara ${ }^{1}$. 2012. Analisis Penerapan International Accounting Standard (IAS) 41pada PT. Sampoerna Agro, Tbk. Vol. 1 No.2 Tahun 2012. Semarang : Universitas Diponegoro.

Arfan ikhsan., dkk. 2014. Metodologi Penelitian Bisnis untuk Akuntansi dan Manajemen. Bandung, jl. Cijotang Indah II No. 18-A. Hal 35.

Ariyanto. S, Sukendar. H, dan Heny Kurniawati. 2014. Penerapan PSAK Adopsi IAS 41 Agriculture. Vol. 5 No. 1, Mei 2014. Hal 186 - 193. Jakarta : BINUS University.

BAPEPAM. 2002. Pedoman Penyajian dan Pengungkapan Laporan Keuangan Emoten atau Perusahaan Publik Industri Perkebunan. Surat Edaran Bapepam. Online : www.bapepam.go.id. Diunduh 3 Desember 2017.

Elad, C dan K. Hebohn. 2011. Implementing Fair Value Accounting in the Agricultural Sector". The Institute Of Chartered Accountans of Scotland. Online : www.sciencedirect.com Diunduh tanggal 3 Desember 2017.

Farida Ike. 2014. Analisis Perlakuan Akuntansi Aset Biologis Berdasarkan International Accounting Standard 41 pada PT. Perkebunan Nusantara VII (PERSERO). Surabaya : Universitas Negeri Surabaya. Diakses pada tanggal 18 November 2017.

Farida.F, Rosinta dan R. Pangabean.2015.Analisis dampak Penerapan IAS 41 di Indonesia (Studi Kasus : PT. Perkebunan Nusantara VIII dan United Plantions Berhad. http://Eprints.binus. ac.id/id/eprint/31792. Diakses pada 15 November 2017.

Handoko. 2011. Overview IAS 41: Agriculture. Surabaya. Diakses di https://rogonyowosukmo.wordpress.com/2011.

hhtp://www.jagoakuntansi.com/2017/04/2855. Akuntansi Perkebunan (Agrikultur) diakses 15 desember 2017.

hhtp://agrikultur4603.blogspot.co.id/2017/04/agrikultur.html?m=1. Akuntansi perkebunan dan perternakan diakses 15 desember 2017.

hhtp://jtanzilco.com/blog/detail/681/slug/bagaimana-perlakuan-akuntansi-untuk-aset-biologis. Diakses 15 November 2017.

International Accounting Standard Committee (IASC). 2009. International Accounting Standar No. 41, Agriculture. Diakses 4 November 2017

Kurniawati Heny. 2013. Tinjauan Rencana Adopsi IAS 41 Pada Perusahaan Agrikultur di Bursa Efek Indonesia. Vol. 4 No. 1 Mei 2013.Hal 461 - 472. Jakarta : BINUS University.

Mardiana. 2014. Analisis Perbandingan Penyusutan Aset Biologis Karet Pada PT. Perkebunan Nusantara VII (Persero) Unit Usaha Mulindas. Vol. 1 No. 1 Agustus 2014. 
Penttinen, M., A. Latukka, H. Merilainen, O. Salminen, dan E. Uotila. 2004. "IAS Fair Flue and Forest Evaluation On Farm Foresty". www.sciencedirect.com. Diakses Tanggal 14 November 2017.

Prasetya, F.D. 2011. Perkembangan Sejarah Akuntansi Keuangan di Indonesia. Jurnal Ilmiah Mahasiswa Akuntansi.

PT. Perkebunan Nusantara IV. 2016. Laporan Tahunan PTPN IV 2016. Diakses dari http://www. ptpn4.co.id/. Diakses pada 04 Desember 2017.

Rafika. S. Putri. 2014 . Analisis Perbandingan Pelaporan dan Pengungkapan Aset Biologis Sebelum dan Setelah Penerapan IAS (International Accounting Standards) 41 pada PT.Astra Agro Lestari, Tbk. Surabaya : Universitas Negeri Surabaya. Diakses pada tanggal 18 November 2017.

Ridwan. A. 2011. Perlakuan Akuntansi Aset Biologis PT. Perkebunan Nusantara XIV Makassar (Persero). Skripsi. Makassar : Universitas Hasanuddin.

Sayosky. F. Klaas. 2013. Komparasi Akuntansi untuk Aset Biologis Menurut IAS 41 dan PSAK 16. Skripsi. Salatiga : Universitas Kristen Satya Wacana.

Sharlica Evelyn.2017. Bagaimana Perlakuan Akuntansi Untuk Aset Biologis. Sumber jtanzilo.com/ b;og/detail/681/slug/bagaimana-perlakuan-akuntansi-untuk-aset-biologis. Diakses pada 15 November 2017 .

Sonbay, Y.Y. 2010. Perbandingan Biaya Hostoris dan Nilai Wajar - Historical Cost Versus Fair Value. Kajian Akuntansi, h. 1-8, vol. 2 no.1. Diakses tanggal 04 Desember 2017.

Suardjono.2008. Teori Akuntansi-Perekayasaan Pelaporan Kauangan. Edisi Ketiga. Yogyakarta : Badan Penerbit Fakultas Ekonomi (BPFE).

Tim Penyusun Fakultas Ekonomi Universitas Malikussaleh. 2014. Buku Panduan Penulisan Skripsi \& LKP. Lhokseumawe : Univrsitas Malikussaleh.

Utomo.R, dan Nur Laila Khumaidah. 2014. Perlakuan Akuntansi Aset Biologis (Tanaman Kopi) Pada PT. Wahana Graha Makmur - Surabaya. Vol. 03 No. 01, Juli 2014.

Wauran.A, ${ }^{1}$, Sondakh. ${ }^{2}$, dan Joseph N Tangon. 2015. Tangon ${ }^{3}$ Pengembangan Model Aset Biologis Tanaman Kelapa Berbasis International Accounting Standards (IAS) 41. Vol. 001, Tahun 2015. Manado : Politeknik Negeri Manado.

www.wikipedia.com.Diakses.https://en.m.wikipedia.org/wiki/International_Financial_Reporting Standards. Diakses pada 15 November 2017. 